\title{
The role of novel antihyperglycaemic agents in the treatment of Type 2 diabetes - from glycaemic control to cardiovascular protection
}

\author{
Tatjana Žunić́, Milojka Ponjavić \\ Apoteka Beograd, Velimira Bate Živojinovića 16/4, Belgrade, Serbia \\ *Corresponding author: Tatjana Žunić, E-mail: tzunic@sbb.rs
}

\begin{abstract}
The advent of new antihyperglycaemic drugs has not only brought a greater variety of drugs used to control glycaemia, but has introduced changes in other important aspects of Type 2 diabetes (T2DM) therapy, cardioprotection and renoprotection. All new antihyperglycaemic drugs: sodium glucose co-transporter 2 (SGLT2) inhibitors, glucagon-like peptide-1 receptor agonists (GLP-1 agonists), and dipeptidyl peptidase-4 (DPP-4) inhibitors were subjects of Cardiovascular Outcome Trials - CVOTs. Cardiovascular protection is not considered to be class specific, especially in the GLP-1 agonist group, but more likely drug specific. Based on the result of CVOTs, some drugs received from Food and Drug Administration labelled indications of reduction of the risk of major adverse cardiovascular events in adults with type 2 diabetes mellitus and established cardiovascular disease (liraglutide, semaglutide, dulaglutide, canagliflozin, empagliflozin, dapagliflozin). Cardiology and diabetology societies acknowledged CVOTs results in various ways. American Diabetes Associations (ADA) and European Association for the Study of Diabetes (EASD) still consider metformin as first-line drug but introduced precise criteria for utilization of GLP-1 agonists and SGLT2 inhibitors for primary as well as secondary cardiovascular (CV) prevention. The Canadian Diabetes Association (Diabetes Canada) recognized the use of an antihyperglycaemic agent with demonstrated CV outcome benefit in secondary prevention only. The European Society of Cardiology (ESC) favoured cardiovascular protection effects and chosen GLP-1 agonists and SGLT2 inhibitors to be first- line therapy in a treatment-naïve patient with atherosclerotic cardiovascular disease (ASCVD). National Institute for Health and Care Excellence (NICE) did not change the previous position of utilisation of novel antihyperglycemic drugs only for achieving adequate glycaemic control either as monotherapy when metformin is contraindicated or not tolerated or as add-on therapy in dual and triple combinations of antihyperglycemic drugs.
\end{abstract}

Keywords: Type 2 Diabetes, cardiovascular protection, sodium-glucose co-transporter 2 (SGLT2) inhibitors, glucagon-like peptide-1 receptor agonists (GLP-1 agonists), Cardiovascular Outcome Trials 


\section{Introduction}

Diabetes mellitus (DM) is a group of metabolic disorders, of a chronic and progressive nature, whose main manifestation is hyperglycaemia due to disorders in insulin secretion, insulin action, or both (1). In addition to changes in carbohydrate metabolism, there are also changes in lipid and protein metabolism. The etiological classification used today distinguishes four basic types of diabetes (2): Type 1 diabetes (T1DM), Type 2 diabetes (T2DM), other specific forms of diabetes, and Gestational Diabetes. T2DM is the result of changes that can be ranked from dominant insulin resistance to dominant insulin secretion deficiency associated with insulin resistance (2). Acute symptoms of DM manifested as polyuria, polydipsia, weight loss, fatigue are due to prominent hyperglycaemia. In the long run, metabolic changes lead to chronic complications which are the major cause of morbidity and mortality in people with diabetes. The chronic effects of diabetes on target organs can be classified into vascular and non-vascular. Vascular complications are usually divided into microvascular (retinopathy, neuropathy, and nephropathy) and macrovascular complications (coronary artery disease, peripheral arterial disease, and cerebrovascular disease). Microvascular complications occur only in individuals with diabetes, while macrovascular complications related to atherosclerosis occur more frequently in individuals with diabetes, but are not diabetes specific (3). Diabetes represents a notable independent atherosclerotic cardiovascular disease (ASCVD) risk. Most people with type 2 diabetes also have additional risk factors such as hypertension, dyslipidaemia, obesity, physical inactivity, chronic kidney disease (CKD), and smoking (4). T2DM increases the risk of cardiovascular disease (CVD) by 2-4-fold and accounts for $60-75 \%$ of deaths in persons with DM (5). The general goals of diabetes therapy are to reduce symptoms associated with hyperglycaemia and to prevent or reduce acute metabolic decompensation and chronic complications of target organs (3). Today, the term comprehensive diabetes care is used for optimal therapy that includes glycaemic control, treatment of comorbid conditions (dyslipidaemia, hypertension, obesity), and screening and treatment of diabetes complications (3). The basis of this approach is the definition of individual target values for glycaemia, blood pressure, and blood lipid levels, regular monitoring of complications, changes in diet, appropriate physical activity, and laboratory monitoring of appropriate parameters (2). Type 2 diabetes is a progressive disease that leads to a gradual loss of beta-cell function, which results in the limited effectiveness of monotherapy in maintaining glycaemic control. The stepwise addition of hypoglycaemic agents to maintain an agreed therapeutic target (sequential regimen) has been supported by several clinical studies $(6,7)$. Initially administered dual therapy may achieve greater reduction in HbAlc than monotherapy, but for the time being, there is little evidence that this approach is superior in maintaining glycaemic control or in slowing the progression of diabetes to stepwise administration $(6,7)$. Since the early 2000 s, the number of diabetes 
drugs has more than doubled. Non-insulin antihyperglycaemic drugs can be classified into the following groups according to the underlying pathophysiological process they modify: Insulin secretagogues (sulfonylurea derivatives, meglitinides, glucagon-like peptide-1 receptor agonists (GLP-1 agonists) and dipeptidyl peptidase-4 (DPP-4) inhibitors), suppressors of gluconeogenesis (biguanides - metformin), insulin resistance drugs (thiazolidinediones), drugs that affect the rate or extent of glucose absorption (analogues of the amyloid polypeptide and alpha-glucosidase inhibitor), glycosuria promoting drugs (sodium-glucose co-transporter 2 (SGLT2) inhibitors) $(3,4)$. This categorisation is arbitrary, as each drug influences multiple processes (e.g. metformin reduces hepatic glucose production and promotes glucose uptake in peripheral tissues) (3). The antihyperglycaemics are often categorized into two goups: the traditional agents (insulin, metformin, and sulfonylurea derivatives) and novel antihyperglycaemic agents (SGLT2 inhibitors, GLP-1 agonists and DPP-4 inhibitors).

\section{Glycaemic control and cardiovascular protection}

Benefits of blood pressure control and treatment of dyslipidemia as part of CVD protection in patients with T2DM were well established in the last two decades, while the effects of near normalization of blood glucose on CVD reduction have been perplexed (5). In clinical trials of sulfonylurea derivatives, cardiovascular outcomes were not the primary goals, but comparisons were made with metformin therapy in terms of its impact on increasing the risk of overall cardiovascular mortality, the risk of myocardial infarction, and stroke. Metformin was superior in all studies (8). An increased risk of congestive heart failure $(\mathrm{CHF})$ with pioglitazone when compared with placebo or other medications was found in several trials (8). The increased incidence of myocardial infarction with rosiglitazone led to the withdrawal of his marketing authorisation in 2015 (8).

Data used to assess the effects of the level of glycaemic control on macrovascular complications are from the three landmark trials: Action to Control Cardiovascular Risk in Diabetes (ACCORD), Action in Diabetes and Vascular Disease: Preterax and Diamicron MR Controlled Evaluation (ADVANCE), and Veterans Affairs Diabetes Trial (VADT) which all dealt with patients with long-standing T2DM and either known cardiovascular disease (CVD) or high cardiovascular risk $(10,11,12)$. The United Kingdom Prospective Diabetes Study (UKPDS), which looked at the effects of intense glycaemic control of sulfonylurea, metformin, and insulin derivatives in people with newly diagnosed diabetes is the still mainstream study for assessing effects of glycaemic control therapy (13). UKPDS found no statistically significant reduction in cardiovascular events. However, UKPDS34, which investigated the impact of metformin intensive (median HbA1c of $7.4 \%$ ) vs conventional (median HbA1c 8\%) therapy in the obese subgroup, showed a relative reduction in risk all-cause mortality by $36 \%(8,13)$. The 
ACCORD study was discontinued, because of an increase in all-cause mortality in the intensive regimen group, with a similar increase in cardiovascular mortality (10). A clear explanation for the excess mortality in the intensive treatment group was not presented by the later analysis of the ACCORD data (9). In a VADT study, a statistically minimal increase in all-cause mortality was observed in the group with stricter glycaemic control (14). Longer-term follow-ups of these trails provided data for a new aspect of glycaemic control. At the 10-year observation period of UKPDS, subjects from the intensive glycaemic control group had a significant long-term reduction in myocardial infarction (15\% with sulfonylurea or insulin as initial pharmacotherapy, 33\% with metformin as initial pharmacotherapy) and all-cause mortality (13\% and $27 \%$, respectively) (9). ACCORD, ADVANCE, and VADT showed no significant reduction in cardiovascular outcomes with intensive glycaemic control through follow-up over 3.5-5.6 years. However, a 10-year follow-up of the VADT cohort showed a reduction in the risk of cardiovascular events, with no benefit in cardiovascular or overall mortality (9). Differences in glycaemic targets, therapeutic approaches, and population characteristics may cause this variety of effects across studies (9). Unlike the UKPDS subjects, patients in the VADT and ACCORD trials had more advanced diabetes (elderly, with longer DM duration and with pre-existing cardiovascular disease or multiple cardiovascular risk factors) (9). The slow emergence of benefits of intensive glucose control may be explained by the prevention of microvascular disease for some studies show that the risk of CV disease and mortality increases with the number of micro-vascular complications (15). Also, it is proposed that the pathophysiology of micro- and macro-vascular damage may have more common features than usually thought so, in the long term, microvascular prevention may result in less macro-vascular complications as well $(16,17)$. Good glycaemic control is itself essential for reducing the development rate of microvascular complications in patients with T2DM, as several controlled randomized trials have shown that reducing $\mathrm{HbA} 1 \mathrm{c}$ to a mean of $6.4-8.0 \%$ reduces the development of microvascular complications $(8,9)$. The precise reasons for the failure in CVD event reduction with intensive glycaemic control remain to be established. It has been suggested that the lack of significant beneficial effects of intensive glucose control may be influenced by hypoglycaemia which is a common complication of DM management (5). This is supported by findings that severe hypoglycaemia is a potent marker of high absolute risk of cardiovascular events and mortality (18). Although causality is unproven, avoidance of hypoglycaemia is a key goal of the diabetes mellitus treatment. All this led to the concept of target and treatment individualization (19). Given that stricter glycaemic targets are accompanied by a notable increase in the risk of hypoglycaemia, the risk of providing lower glycaemic values outweighs the potential benefit of reducing the development of complications especially in a patient with a history of severe hypoglycaemia, evident microvascular and macrovascular complications, marked comorbidities, long-standing diabetes in which glycaemic goals are difficult to achieve 
despite all interventions applied (9). Treatment individualisation i.e. selection and introduction of a new drug (s) in the context of CVD safety and prevention is even more complicated with the possibility that some glucose-lowering drugs could increase CV risk (20).

\section{New antihyperglycaemic agents and cardiovascular protection}

As intensive glycaemic control is to some extent associated with a reduction in macrovascular complications, studies to prove that a drug apart of its hypoglycaemic effect has a cardiovascular protective effect must be carefully designed. First of all, the comparison groups of subjects should have minimal differences in glycaemia (9). Results from UKPDS have long been the evidence base for the notion that metformin is the only drug that has been shown to reduce overall mortality and mortality due to cardiovascular disease in people with T2DM (13). Most trials with the traditional antihyperglycaemic drugs typically had younger participants with relatively recent onset of diabetes and low $\mathrm{CV}$ risk and mostly excluded individuals with established CVD. They had low CV event rates too, so estimates of the CV safety of these drugs should be carefully reconsidered (13). Due to the controversy with the increased incidence of myocardial infarction with rosiglitazone, regulatory agencies (FDA 2008 and EMA 2012) introduced a recommendation on cardiovascular safety assessment within their clinical trial guides for diabetes prevention and treatment $(20,21,22)$. It was advocated that in the phase- 3 clinical trials all new antihyperglycaemic have to demonstrate that their use would not lead to unacceptably high rates of CVD events (upper bound of the $95 \%$ confidence interval for major adverse CVD event not to exceed 1.8). Also post-approval, in phase-4 trails in patients with pre-existing CVD, drugs would need to further demonstrate a CVD event rate not exceeding the upper bound of the $95 \%$ confidence interval of 1.3. (21). This led to an increase in the number of multicentre prospective placebo-controlled studies examining cardiovascular outcomes with new antihyperglycaemic drugs with a minimum follow up of 2 years (Cardiovascular Outcome Trials - CVOTs). Although the purpose of such regulatory requirements was to monitor safety, i.e. to determine the noninferiority of primary monitoring outcomes, some studies have also found drug superiority to placebo in terms of cardiovascular protection. In most studies, the primary outcome for monitoring safety and efficacy was the composite endpoint consisting of the time until the first occurrence of the following 3 Major Adverse Cardiovascular Events (MACE): CV death, non-fatal myocardial infarction and non-fatal ischemic stroke (3point MACE or 3P-MACE). A 4-point MACE was used as a secondary composite outcome, with the addition of the urgent revascularization procedure due to unstable angina. Other outcomes such as: time to serum creatinine duplication; decrease in estimated glomerular filtration rate (eGFR), time to onset of terminal renal failure, development of albuminuria, hospitalization for heart failure were position as primary or secondary outcomes throughout various CVOTs $(23,24)$. When interpreting the results 
of CVOTs with novel antihyperglycaemic drugs, it should be taken into account that the majority of the subjects had already manifested cardiovascular disease or multiple CV risk factors and that they needed more than one antihyperglycaemic (longer course of the disease). There are little data as to whether the findings can be extrapolated to people with newly diagnosed diabetes, or those with medium or low CV risk (25). The cardioprotection effect of these drugs had been compared only with placebo or traditional antihyperglycaemics, so there is no information on their comparative efficacy in terms of reducing the risk of complications, but the results of the available CVOTs also highlight different effects of SGLT2 inhibitors and GLP-1 agonists concerning heart failure, stroke, and diabetic renal disease (25).

\section{Sodium-glucose co-transporter 2 inhibitors}

Sodium-glucose co-transporter 2 inhibitors (SGLT2i) reduce renal glucose reabsorption and promote urinary glucose loss and natriuresis. Currently in the clinical use for T2DM are: dapagliflozin, canagliflozin, empagliflozin, ertugliflozin, ipragliflozin, luseoglifozin, tofogliflozin (26). The first four representatives have marketing authorisation in the European Union and the United States of America. These drugs do not interfere with endogenous glucose production and act independently of insulin secretion and insulin action (2). Several studies of these drugs have shown significant efficacy in reducing glycaemia and moderate efficacy in reducing blood pressure, lipids, uric acid and body weight (27). Monotherapy leads to a decrease in HbAlc by $0.7-1.0 \%$, a decrease in blood pressure by 2-4 $\mathrm{mm} \mathrm{Hg}$, and a loss of 2-4 $\mathrm{kg}$ of body weight (3). Initial rapid weight loss is caused by fluid loss due to glycosuria and natriuresis, however, chronic therapy also revealed a loss of visceral adipose tissue (28). A reduction in preload (secondary to natriuresis and osmotic diuresis) and afterload (reduction in blood pressure and improvement in vascular function) are proposed to be accountable for the rapid effect of SGLT2 inhibitors on CV (29). Beneficial effects on adipokines and cytokines with a reduction of necrosis and cardiac fibrosis have been also suggested to contribute to $\mathrm{CV}$ protection (29). Some authors consider that a central mechanism with the restoration of the tubule-glomerular feedback and improvement of circulating volume control could be a part of SGLT2 is mechanism of action (30). The post-marketing monitoring of this group of drugs has led to several significant warnings in 2015-2018. The FDA and the European Medicines Agency (EMA) have issued warnings regarding the following side effects: the occurrence of atypical ketoacidosis during therapy with SGLT2 inhibitors (31, 32) and the occurrence of severe genital infections (necrotizing fasciitis perineum) (33). The impact of SGLT2 inhibitors on bone density reduction and increased risk of fractures is still controversial, although in 2015 the FDA issued a warning for the drug canagliflozin based on the results of a CANVAS study (34). Other studies have not found an increased risk of fractures (35). An increased risk of lower limb amputation during the administration of canagliflozin was found during the CANVAS study (36). The CV and 
renal safety of SGLT2 inhibitors are being evaluated in nine trials enrolling 62.378 patients (37). For the time being, four CVOTs are a key in the interpretation of SGLTis in CVD protection: EMPA-REG, CANVAS, DECLARE TIMI-58, and Dapa-HF (Table I and II).

Table I Overview of basic characteristics of CVOT studies with SGLT 2 inhibitors.

Tabela I Pregled osnovnih karakteristika CVOT studija sa SGLT 2 inhibitorima.

\begin{tabular}{|c|c|c|c|c|c|c|}
\hline $\begin{array}{l}\text { Study name } \\
\text { (reference) }\end{array}$ & Intervention & Population Characteristics & $\mathbf{N}$ & $\begin{array}{l}\text { Mean } \\
\text { Age } \\
(\mathbf{y})\end{array}$ & $\begin{array}{l}\text { Median } \\
\text { Follow- } \\
\text { up (y) }\end{array}$ & $\begin{array}{l}\text { Existing } \\
\text { ASCVD } \\
(\%)\end{array}$ \\
\hline $\begin{array}{l}\text { EMPA-REG } \\
\text { OUTCOME } \\
\qquad(38)\end{array}$ & $\begin{array}{l}\text { empagliflozin } \\
10 \mathrm{mg} \text { or } 25 \mathrm{mg} \\
\text { once daily } \\
\text { vs. placebo }\end{array}$ & $\begin{array}{l}\text { T2DM plus } \\
\text { MI, multi-vessel CAD, CAD with } \\
\text { ischemia/UA, stroke, or PAD. }\end{array}$ & 7020 & 63.1 & 3.1 & 100 \\
\hline $\begin{array}{l}\text { CANVAS } \\
\text { STUDY } \\
(40,41)\end{array}$ & $\begin{array}{l}\text { canagliflozin } 100 \mathrm{mg} \text { or } \\
300 \mathrm{mg} \text { vs. placebo }\end{array}$ & $\begin{array}{l}\text { T2DM plus } \\
\geq 30 \text { yrs old with history of } \\
\text { cardiovascular }(\mathrm{CV}) \text { event, or } \\
\geq 50 \text { yrs old with high risk of } \mathrm{CV} \\
\text { events }\end{array}$ & 10142 & 63 & 3.6 & 66 \\
\hline $\begin{array}{l}\text { DECLARE- } \\
\text { TIMI-58 } \\
(42)\end{array}$ & $\begin{array}{l}\text { dapaglifllozin once daily } \\
10 \mathrm{mg} \text { vs. placebo }\end{array}$ & $\begin{array}{l}\text { T2DM plus } \\
\text { CAD, CVA, PAD or } \\
\text { Men } \geq 55 \text { y or women } \geq 60 \text { y with } \\
\text { hypertension, dyslipidemia, or } \\
\text { smoking. }\end{array}$ & 17160 & 63.9 & 4.2 & 40.6 \\
\hline $\begin{array}{l}\text { DAPA-Hf } \\
(43)\end{array}$ & $\begin{array}{l}\text { dapaglifozin } 10 \mathrm{mg} \text { once } \\
\text { daily vs. placebo }\end{array}$ & $\begin{array}{l}\text { New York Heart Association class } \\
\text { II, III, or IV heart failure and an } \\
\text { ejection fraction } \leq 40 \%\end{array}$ & 4744 & & 1.5 & \\
\hline $\begin{array}{c}\text { CREDENCE } \\
\text { (44) }\end{array}$ & $\begin{array}{l}\text { canaglifozin } 100 \mathrm{mg} \\
\text { once daily } \\
\text { vs. placebo }\end{array}$ & $\begin{array}{l}\text { T2DM plus } \\
\geq 30 \text { yrs old with chronic kidney } \\
\text { disease }\end{array}$ & 4401 & 63 & 2.6 & 50.4 \\
\hline
\end{tabular}

Abbreviations: CAD, coronary artery disease; CVD, cardiovascular disease; CVA, cerebrovascular accident; MI, myocardial infarction; PAD, peripheral arterial disease; T2DM, type 2 diabetes; UA, unstable angina. 
Table II Overview of cardiovascular endpoints of CVOT studies with SGLT-2 inhibitors.

Tabela II Pregled kariovaskularnih ishoda CVOT studija sa SGLT2 inhibitorima.

\begin{tabular}{|c|c|c|c|c|c|c|}
\hline $\begin{array}{l}\text { Study name } \\
\text { (reference) }\end{array}$ & $\begin{array}{c}\text { Composite } \\
\text { 3-point MACE } \\
\text { (HR) }\end{array}$ & $\begin{array}{c}\text { CV } \\
\text { Death } \\
(\text { HR) }\end{array}$ & $\begin{array}{l}\text { Myocardial } \\
\text { Infarction } \\
\text { (HR) }\end{array}$ & $\begin{array}{c}\text { Stroke } \\
\text { (HR) }\end{array}$ & $\begin{array}{c}\text { Hospitalisation } \\
\text { for unstable } \\
\text { angina } \\
\text { (HR) }\end{array}$ & $\begin{array}{l}\text { Hospitalisation } \\
\text { for heart failure } \\
\text { (HR) }\end{array}$ \\
\hline $\begin{array}{c}\text { EMPA-REG } \\
\text { OUTCOME } \\
(38)\end{array}$ & $\begin{array}{c}0.86 \\
(0.74-0.99)\end{array}$ & $\begin{array}{c}0.62 \\
(0.49-0.77)\end{array}$ & $\begin{array}{c}0.87 \\
(0.7-1.09)\end{array}$ & $\begin{array}{c}1.18 \\
(0.89-1.56)\end{array}$ & $\begin{array}{c}0.99 \\
(0.74-1.34)^{1}\end{array}$ & $\begin{array}{c}0.65 \\
(0.5-0.85)^{1}\end{array}$ \\
\hline $\begin{array}{c}\text { CANVAS } \\
\text { STUDY } \\
(40,41)\end{array}$ & $\begin{array}{c}0.86 \\
(0.75-0.97)\end{array}$ & $\begin{array}{c}0.87 \\
(0.72-1.06)\end{array}$ & $\begin{array}{c}0.89 \\
(0.73-1.09)\end{array}$ & $\begin{array}{c}0.87 \\
(0.69-1.09)\end{array}$ & / & $\begin{array}{c}0.67 \\
(0.52-0.87)^{1}\end{array}$ \\
\hline $\begin{array}{c}\text { DECLARE- } \\
\text { TIMI-58 } \\
\text { (42) }\end{array}$ & $\begin{array}{c}0.93 \\
(0.84-1.03)\end{array}$ & $\begin{array}{c}0.83 \\
(0.73-0.95)\end{array}$ & $\begin{array}{c}0.89 \\
(0.77-1.01)\end{array}$ & $\begin{array}{c}1.01 \\
(0.84-1.21)\end{array}$ & I & $\begin{array}{c}0.73 \\
(0.61-0.88)\end{array}$ \\
\hline $\begin{array}{c}\text { DAPA-Hf } \\
(43)\end{array}$ & I & $\begin{array}{c}0.82 \\
(0.69-0.98)^{2}\end{array}$ & I & I & I & \\
\hline $\begin{array}{c}\text { CREDENCE } \\
\text { (44) }\end{array}$ & $\begin{array}{c}0.80 \\
(0.67-0.95)^{1}\end{array}$ & $\begin{array}{c}0.78 \\
(0.61-1.00)^{1}\end{array}$ & I & I & I & $\begin{array}{c}0.61 \\
(0.47-0.80)\end{array}$ \\
\hline
\end{tabular}

HR-hazard ratio ( $95 \%$ confidence interval), ${ }^{1}$ Secondary outcome, ${ }^{2}$ Exploratory outcome

The Empagliflozin Cardiovascular Outcome Event Trial in Type 2 Diabetes Mellitus Patients (EMPA-REG OUTCOME) study compared empagliflozin and placebo over 3.1 years in addition to standard hypoglycaemic therapy (metformin, insulin, sulfonylurea) in patients with cardiovascular disease defined by the presence of at least one of the following conditions: myocardial infarction at least two months ago, multivascular coronary disease, coronary artery disease in one artery with a positive load test, hospitalization due to unstable angina during the previous year (38). As there was no DPP-4 inhibitor class medication in the primary therapy subjects, the efficacy of empagliflozin in concurrent use with DPP-4i in the prevention of cardiovascular mortality was not conclusively established (39). Empagliflozin was superior to a placebo in preventing the composite primary outcome of 3P-MACE. The dominant part in the 
composite primary outcome was a significant reduction in cardiovascular deaths, while there was no significant reduction in non-fatal IM or non-fatal stroke. In a secondary analysis of data from the EMPA-REG OUTCOME study, empagliflozin showed a reduction in the risk of hospitalization due to heart failure (HF) compared to placebo (38). The effects of canagliflozin on cardiovascular events in adults with type 2 diabetes and established cardiovascular disease or with at least two cardiovascular risks were observed in a CANVAS program (CANagliflozin cardioVascular Assessment Study) that integrated the findings two randomized, multi-national, double-blind, multicentre, parallel group controlled clinical studies, CANVAS and CANVAS R (40, 41). Both studies had similar inclusion and exclusion criteria. Observed subjects were with DM2 of an average duration of 13.5 years, either older than 30 years with symptomatic atherosclerotic vascular disease (coronary, cerebrovascular or peripheral) or over 50 years of age with at least $2 \mathrm{CV}$ risk factors (diabetes longer than 10 years, systolic blood pressure greater than $140 \mathrm{mmHg}$ with one or more antihypertensive drugs, smoking, microalbinuria, macroalbuminuria, HDL cholesterol less than $1 \mathrm{mmol} / \mathrm{L}$ ) (40). The primary endpoint of CANVAS program was the time until the occurrence of the composite outcome of 3P-MACE. A secondary goal was all-cause deaths and cardiovascular mortality. The composite outcome of 3P-MACE was found to be significantly decreased in the canagliflozin group compared to the placebo group, but only in the subgroup of subjects with pre-existing cardiovascular disease. Overall findings related to the time of occurrence of MACE were consistent in the subgroup of subjects with an eGFR of 30 to $60 \mathrm{~mL} / \mathrm{min} / 1.73 \mathrm{~m}^{2}$. Each component of the 3P-MACE outcome (cardiovascular mortality, non-fatal IM, non-fatal stroke) contributed positively to the overall composite outcome, i.e. there were no statistical differences in the individual components of the composite outcome $(40,41)$. Compared with placebo, canagliflozin decreased the risk of hospitalization due to HF, the progression of albuminuria in patients with normal or microalbuminuria at baseline. The CANVAS Program also monitored the time to the first nephropathic event (measured as the time to serum creatinine duplication) and empagliflozin had a smaller increase in time than placebo (40). The Dapagliflozin Effect on Cardiovascular Events-Thrombolysis in Myocardial Infarction 58 (DECLARE-TIMI 58) was a multi-national, randomized, double-blind, placebocontrolled Phase IIIB trial conducted to determine the effect of dapagliflozin on cardiovascular outcomes when added to current antihyperglycaemic therapy in patients with type 2 diabetes with either established cardiovascular disease or cardiovascular risk factors. This trial enrolled a greater proportion of participants without prior established CVD but with multiple risk factors (59.4\%) and had longer follow-up (median 4.2 years) than other CVOTs with SGLT2is (42). Dapagliflozin demonstrated CV safety, but not the MACE endpoint benefit (numeric but not statistically significant decrease). On the other hand, dapagliflozin was associated with benefit for the co-primary efficacy endpoint of cardiovascular death or hospitalisation for heart failure (hHF), as well as renal endpoints 
(25, 42). Although designed as HF study, Dapa-HF (Study to Evaluate the Effect of Dapagliflozin on the Incidence of Worsening Heart Failure or Cardiovascular Death in Patients With Chronic Heart Failure) recruited patients with heart failure with reduced ejection fraction (HfrEF) with and without T2DM (43). Considering that the benefit for reduction of mortality rate and HF events with dapagliflozin was significant in both subgroups, it can be concluded that the effects of dapagliflozin on these endpoints are independent of HbA1c (43). Whether SGLT2 inhibitors also reduce risk in patients with heart failure with preserved ejection fraction is still awaiting the results of ongoing studies. Evaluation of the Effects of Canagliflozin on Renal and Cardiovascular Outcomes in Participants with Diabetic Nephropathy (CREDENCE) trial also prospectively collected CV outcomes, as required by the FDA. As the goal of this study was to assess whether canagliflozin has a renal and vascular protective effect in reducing the progression of renal impairment relative to placebo in participants with type 2 diabetes mellitus, Stage 2 or 3 chronic kidney disease and macroalbuminuria, the primary outcome measures were CKD related (44). It is still uncertain whether heterogeneity in the point estimates of benefits and harms with SGLT2 inhibitors is the result of differences in the effects of the medications, the design, and conduct of the trials, or something else. Based on the results of above-mentioned studies with SGLT2 inhibitors The Food and Drug Administration (FDA) has already approved the prevention-related indication in addition to the therapeutic indication of improving glycaemic control in adults with type 2 diabetes mellitus. Empagliflozin and canagliflozin may be used "to reduce the risk of major adverse cardiovascular events in adults with type 2 diabetes mellitus and established cardiovascular disease." (45 p1, 46 p1). Canagliflozin also has label indication "to reduce the risk of end-stage kidney disease, doubling of serum creatinine, cardiovascular death, and hospitalization for heart failure in adults with type 2 diabetes mellitus and diabetic nephropathy with albuminuria." (46 p1) Dapagliflozin does not have an indication related to prevention of MACE, but can be used "to reduce the risk of hospitalization for heart failure in adults with type 2 diabetes mellitus and established cardiovascular disease or multiple cardiovascular risk factors." (47 p1). Dapagliflozin may be also used in patients with heart failure with reduced ejection fraction (classes II - IV by the New York Heart Association) to reduce the risk of cardiovascular death and hospitalization for heart failure (non-diabetic indication) (47 p1).

\section{Glucagon-like peptide-1 receptor agonists}

The effects on glycaemic control of this group of drugs are achieved by the activation of the GLP-1 receptor and mimicking of the physiological action of incretins (8). GLP-1 receptors are distributed on Langerhans island cells, peripheral and central nervous system cells, heart, blood vessel endothelium, kidneys, lungs, and gastrointestinal mucosa. The binding of agonists to the GLP1 receptor activates several signalling pathways. In the pancreas, GLP-1 agonists bind to beta cells and increase 
insulin synthesis and exocytosis in a glucose-dependent manner. There are in vitro findings that GLP-1 agonists increase proliferation and decrease beta-cell apoptosis, but a clinical link between the administration of these drugs and the change in disease course has not been established (48). A decrease in glucagon secretion has also been reported, but it is not fully understood whether this is due to an increase in somatostatin and insulin secretion or whether the mechanism involves direct activation of GLP-1 receptors on beta cells (49). Cytoprotective effects on animal models of cardiomyocytes and nerve cells have also been reported. Possible explanations for the positive cardiovascular effects of GLP-1 receptor agonists are based on the findings that stimulation of the GLP-1 receptor in the heart leads to increased NO production, increased glucose uptake into cardiomyocytes, and improved coronary flow. The positive effect of GLP-1 receptor stimulation on suppression of atherosclerosis has been demonstrated (50). Activation of the GLP-1 receptor in the central nervous system is considered to be responsible for the effects this group of drugs has on reducing appetite and increasing the feeling of satiety, delaying gastric emptying, but also on side effects such as nausea (48)._To date, the following GLP-1 agonists have been in use: exenatide, liraglutide, albiglutide, dulaglutide, lixisenatide, and semaglutide. The manufacturer of albiglutide, GlaxoSmithKline, withdrew the drug from the market at the end of 2018 due to financial failure (51). All of the licenced medicines in this group are for subcutaneous use only, except semaglutide. The oral semiglutide formulation has been approved by the FDA and Health Canada, while still in the registration process in Europe (52). All GLP-1 agonists have been tested in CVOTs including albiglutide (Table III and IV). 
Table III Overview of basic characteristics of CVOT studies with GLP-1 agonists.

Tabela III Pregled osnovnih karakteristika CVOT studija sa GLP-1 agonistima.

\begin{tabular}{|c|c|c|c|c|c|c|}
\hline $\begin{array}{l}\text { Study name } \\
\text { (reference) }\end{array}$ & Intervention & $\begin{array}{l}\text { Population Characteristics } \\
\text { Type-2 diabetes mellitus and one } \\
\text { of the following: }\end{array}$ & $\mathbf{N}$ & $\begin{array}{c}\text { Mean } \\
\text { Age (y) }\end{array}$ & $\begin{array}{l}\text { Median } \\
\text { Follow- } \\
\text { up (y) }\end{array}$ & $\begin{array}{l}\text { Existing } \\
\text { ASCVD } \\
(\%)\end{array}$ \\
\hline $\begin{array}{c}\text { LEADER } \\
(\mathbf{5 3 )}\end{array}$ & $\begin{array}{l}\text { Liraglutide } \\
1,8 \mathrm{mg} \text { s.c. } \\
\text { once daily } \\
\text { vs. placebo }\end{array}$ & $\begin{array}{l}\text { - Age } \geq 50 \text { y with } \mathrm{CAD}, \mathrm{CVA}, \mathrm{PAD}, \\
\mathrm{HF}, \text { or } \mathrm{CKD} \text { stage } \geq 3 \\
\text { - Age } \geq 60 \text { y with } \\
\text { microalbuminuria/proteinuria, } \\
\text { hypertension with } \mathrm{LVH}, \mathrm{LV} \\
\text { dysfunction,or } \mathrm{ABI} \text { bi }<0.9\end{array}$ & 9340 & 64 & 3.8 & 81 \\
\hline $\begin{array}{c}\text { SUSTAIN-6 } \\
(54)\end{array}$ & $\begin{array}{l}\text { Semaglutide } \\
0,5 \mathrm{mg} \text { or } 1 \mathrm{mg} \\
\text { s.c. once } \\
\text { weekly } \\
\text { vs. placebo }\end{array}$ & $\begin{array}{l}\text { - Age } \geq 50 \text { y with CAD, CVA, PAD, } \\
\mathrm{HF}, \text { or CKD stage } \geq 3 \text {. } \\
\text { - Age } \geq 60 \text { y with } \\
\text { microalbuminuria/proteinuria, } \\
\text { hypertension with LVH, LV } \\
\text { dysfunction,or ABI b0.9. }\end{array}$ & 3297 & 65 & 2.1 & 83 \\
\hline $\begin{array}{c}\text { REWIND } \\
\text { (55) }\end{array}$ & $\begin{array}{l}\text { Dulaglutide } \\
1,5 \mathrm{mg} \text { s.c.once } \\
\text { weekly } \\
\text { vs. placebo }\end{array}$ & $\begin{array}{l}\text {-Age } \geq 50 \text { y withCAD, ischemic } \\
\text { CVA, carotid or PAD, or } \geq 2 \text { of the } \\
\text { following:hypertension, } \\
\text { dyslipidemia, smoking, or obesity. }\end{array}$ & 9901 & 66 & 5.4 & 31 \\
\hline $\begin{array}{c}\text { PIONEER-6 } \\
(56)\end{array}$ & $\begin{array}{l}\text { Semaglutide } \\
\text { p.o.once daily } \\
\text { vs. placebo }\end{array}$ & $\begin{array}{l}\text {-Age of } \geq 50 \text { years with established } \\
\text { cardiovascular or chronic kidney } \\
\text { disease, or } \\
\text {-age of } \geq 60 \text { years with } \\
\text { cardiovascular risk factors only }\end{array}$ & 3183 & 66 & 1.3 & 84.7 \\
\hline $\begin{array}{c}\text { EXSCEL } \\
\text { (57) }\end{array}$ & $\begin{array}{l}\text { Exenatide } \\
2 \text { mg s.c. once } \\
\text { weekly } \\
\text { vs. placebo }\end{array}$ & $\begin{array}{l}\text { CAD, ischemic CVA, } \\
\geq 50 \% \text { carotid artery stenosis, or } \\
\text { PAD. }\end{array}$ & 14752 & 62 & 3.2 & 73 \\
\hline $\begin{array}{c}\text { ELIXA } \\
(58)\end{array}$ & $\begin{array}{l}\text { Lixisenatide } \\
20 \mathrm{mg} \text { s.c. once } \\
\text { daily } \\
\text { vs. placebo }\end{array}$ & $\begin{array}{l}\text { Age } \geq 30 \text { with MI or UA } \\
\text { hospitalization within the previous } \\
180 \text { days }\end{array}$ & 6068 & 60 & 2.1 & 100 \\
\hline
\end{tabular}

Abbreviations: $\mathrm{ABI}$, ankle-brachial index; $\mathrm{CAD}$, coronary artery disease; $\mathrm{CKD}$, chronic kidney disease; CVA, cerebrovascular accident; HDL, high-density lipoprotein; HF, heart failure; LV, left ventricular; LVH, left ventricular hypertrophy; MI, myocardial infarction; PAD, peripheral arterial disease; UA, unstable angina. 
The Liraglutide Effect and Action in Diabetes: Evaluation of Cardiovascular Outcome (LEADER) trial is a multicentre placebo-controlled double-blind clinical trial which goal was to evaluate the effect of liraglutide on cardiovascular outcomes with participants mainly consisted of subjects who had already been on hyperglycaemic drugs and with at least one cardiovascular disease (coronary heart disease, cerebrovascular disease, peripheral arterial disease, cardiac insufficiency, cardiac insufficiency, or renal failure 3 or higher) (53). The primary outcome was the time from randomization to the first occurrence of MACE events. Liraglutide was superior in preventing MACE compared to the placebo. Liraglutide also significantly reduced the risk of extended MACE outcomes, a composite outcome that includes primary MACE, hospitalization due to unstable angina, coronary revascularization, or hospitalization due to heart failure (53). The Trial to Evaluate Cardiovascular and Other Long-term Outcomes with Semaglutide in Subjects with Type 2 Diabetes (SUSTAIN 6) was a double-blind prospective study of the cardiovascular safety of subcutaneous semaglutide with a population of patients diagnosed with DM2 and cardiovascular disease or with presenting CV risks without established CVD (54). The primary composite outcome was the time from randomization to the first onset of a major cardiovascular event (MACE), while the secondary outcome was the time from randomization to the first occurrence of an extended composite cardiovascular event defined as primary MACE plus hospitalization due to unstable angina, coronary and peripheral revascularization, hospitalization due to heart failure (25, 54). After 2.1 median year, a 26\% reduction of the primary 3-point MACE outcome was reported (54). However, there was a higher rate of diabetic retinopathies in the semiglutide group compared to the placebo group. For the time being, it is unclear whether semaglutide itself is the cause of this retinal complication. The greatest increase in diabetic retinopathies appears to be observed in individuals with pre-existing diabetic retinopathy and a rapid decrease in $\operatorname{HbAlc}(25,54)$. The Researching Cardiovascular Events with a Weekly Incretin in Diabetes (REWIND) trial assessed the effects of dulaglutide on MACE as add-on antihyperglycemic therapy in T2DM subjects with and without a prior cardiovascular disease (55). Prior CVD was defined as a history of myocardial infarction, ischaemic stroke, and unstable angina with ECG changes, myocardial ischaemia on imaging or stress test, or coronary, carotid, or peripheral revascularization. REWIND included a greater proportion of individuals with high cardiovascular risk, but without prior established cardiovascular disease (68.5\%) and had longer follow-up (median 5.4 years) than prior CVOTs $(25,55)$. An overall risk reduction in the subpopulations with and without a history of CVD was not different, although the effect of dulaglutide did not reach statistical significance when the groups were considered separately $(25,55)$. A Trial Investigating the Cardiovascular Safety of Oral Semaglutide in Subjects with Type 2 Diabetes (PIONEER 6) is the latest and the smallest CVOT on GLP-1 agonists. It reported a numerical risk reduction for MACE with the use of oral semaglutide (56). A study with exenatide once a week (the Exenatide Study of 
Cardiovascular Event Lowering trial- EXSCEL) did not show a statistically significant reduction in MACE and cardiovascular mortality but had a significant reduction in overall all-cause mortality (57). The Evaluation of Cardiovascular Outcomes in Patients with Type 2 Diabetes after Acute Coronary Syndrome During Treatment with Lixisenatide (ELIXA) showed CV events neutrality with the use of lixisenatide in patients with acute coronary syndrome within 90 days before entering the study (58). As exenatide and lixisenatide have not shown a similar reduction in cardiovascular events as other GLP-1 agonists, these cardiovascular outcomes cannot be considered as a common effect of the group. Most of the CVOTs with GLP-1 receptor agonists, except in the REWIND trial, included small groups of patients with risk factors only (no established CVD), so the evidence of MACE benefit in the lower-risk subgroups are scarce (25). There was no significant effect on hospitalization for HF in LEADER, SUSTAIN 6, and EXSCEL (53, 54, 57). Liraglutide, subcutaneous semaglutide and dulaglutide are approved by the FDA for reduction of the risk of major adverse cardiovascular events in adults with type 2 diabetes mellitus and established cardiovascular disease (1).

Table IV Overview of cardiovascular endpoints of CVOT studies with an agonist of GLP-1 receptors.

Tabela IV Pregled kardiovaskularnih ishoda CVOT studija sa agonistima GLP-1 receptora.

\begin{tabular}{|c|c|c|c|c|c|c|}
\hline $\begin{array}{c}\text { Study name } \\
\text { (reference) }\end{array}$ & $\begin{array}{l}\text { Composite } \\
\text { 3-point } \\
\text { MACE } \\
\text { (HR) }\end{array}$ & $\begin{array}{c}\text { CV } \\
\text { Death } \\
(\mathbf{H R})\end{array}$ & $\begin{array}{c}\text { Myocardial } \\
\text { Infarction } \\
\text { (HR) }\end{array}$ & $\begin{array}{c}\text { Stroke } \\
\text { (HR) }\end{array}$ & $\begin{array}{c}\text { Hospitalisation } \\
\text { for unstable } \\
\text { angina } \\
\text { (HR) }\end{array}$ & $\begin{array}{l}\text { Hospitalisation } \\
\text { for heart failure } \\
\text { (HR) }\end{array}$ \\
\hline $\begin{array}{l}\text { LEADER } \\
\text { (53) }\end{array}$ & $\begin{array}{c}0.87 \\
(0.78-0.97)\end{array}$ & $\begin{array}{c}0.78 \\
(0.66-0.93)\end{array}$ & $\begin{array}{c}0.86 \\
(0.73-1.00)\end{array}$ & $\begin{array}{c}0.86 \\
(0.71-1.06)\end{array}$ & $\begin{array}{c}0.98 \\
(0.76-1.26)^{1}\end{array}$ & $\begin{array}{c}0.87 \\
(0.73-1.05)^{1}\end{array}$ \\
\hline $\begin{array}{c}\text { SUSTAIN-6 } \\
(54)\end{array}$ & $\begin{array}{c}0.74 \\
(0.58-0.95)\end{array}$ & $\begin{array}{c}0.98 \\
(0.65-1.48)\end{array}$ & $\begin{array}{c}0.74 \\
(0.51-1.08)\end{array}$ & $\begin{array}{c}0.61 \\
(0.38-0.99)\end{array}$ & $\begin{array}{c}0.82 \\
(0.47-1.44)^{1}\end{array}$ & $\begin{array}{c}1.11 \\
(0.77-1.61)^{1}\end{array}$ \\
\hline $\begin{array}{l}\text { REWIND } \\
\text { (55) }\end{array}$ & $\begin{array}{c}0.88 \\
(0.79-0.99)\end{array}$ & $\begin{array}{c}0.91 \\
(0.78-1.06)^{1}\end{array}$ & $\begin{array}{c}0.96 \\
(0.79-1.15)^{1}\end{array}$ & $\begin{array}{c}0.76 \\
(0.62-0.94)^{1}\end{array}$ & $\begin{array}{c}1.14 \\
(0.84-1.54)^{1}\end{array}$ & $\begin{array}{c}0.93 \\
(0.77-1.12)^{1}\end{array}$ \\
\hline $\begin{array}{l}\text { PIONEER-6 } \\
\text { (56) }\end{array}$ & $\begin{array}{c}0.79 \\
(0.57-1.11)\end{array}$ & $\begin{array}{c}0.51 \\
(0.31-0.84)^{1}\end{array}$ & $\begin{array}{c}1.18 \\
(0.73-1.90)^{1}\end{array}$ & $\begin{array}{c}0.74 \\
(0.35-1.57)^{1}\end{array}$ & $\begin{array}{c}1.56 \\
(0.60-4.01)^{1}\end{array}$ & $\begin{array}{c}0.86 \\
(0.48-1.55)^{1}\end{array}$ \\
\hline $\begin{array}{c}\text { EXSCEL } \\
(57)\end{array}$ & $\begin{array}{c}0.91 \\
(0.83-1.00)\end{array}$ & $\begin{array}{c}0.88 \\
(0.76-1.02)^{1}\end{array}$ & $\begin{array}{c}0.97 \\
(0.85-1.10)^{1}\end{array}$ & $\begin{array}{c}0.85 \\
(0.7-1.03)^{1}\end{array}$ & $\begin{array}{c}1.05 \\
(0.94-1.18)^{1}\end{array}$ & $\begin{array}{c}0.94 \\
(0.78-1.13)^{1}\end{array}$ \\
\hline $\begin{array}{c}\text { ELIXA } \\
(\mathbf{5 8 )}\end{array}$ & $\begin{array}{c}1.02 \\
(0.89-1.17)\end{array}$ & $\begin{array}{c}0.98 \\
(0.78-1.22)\end{array}$ & $\begin{array}{c}1.03 \\
(0.87-1.22)\end{array}$ & $\begin{array}{c}1.12 \\
(0.79-1.58)\end{array}$ & $\begin{array}{c}1.11 \\
(0.47-2.62)\end{array}$ & $\begin{array}{c}0.96 \\
(0.75-1.23)^{1}\end{array}$ \\
\hline
\end{tabular}

$\mathrm{CV}$ cardiovascular, HR-hazard ratio $\left(95 \%\right.$ confidence interval), ${ }^{1}$ Secondary outcome,

${ }^{2}$ Exploratory outcome 


\section{Dipeptidyl peptidase IV}

Dipeptidyl peptidase IV (DPP-4) is a serine protease, widespread in the body as an ectoenzyme (on blood vessel endothelial cells and $\mathrm{T}$ lymphocyte surface), but also as a circulating form. DPP-4 is crucial for the rapid inactivation of native incretins (GLP1 and GIP). Alogliptin, linagliptin and sitagliptin are competitive inhibitors of DPP-4, whereas vildagliptin and saxagliptin bind this enzyme covalently (3). At therapeutic doses, these drugs reduce DPP-4 activity by more than $95 \%$ for 12 hours. This causes more than a twofold increase in plasma concentrations of active GIP and GLP1 and correlates with increased insulin secretion, decreased glucagon levels, and decreased basal and postprandial hyperglycaemia. DPP-4 inhibition has no direct effects on insulin sensitivity, gastric emptying, and feeling satiety. Bodyweight was not affected by chronic treatment with DPP-4 inhibitors (3). The effects of DPP-4 inhibitors in combination regimens with other antihyperglycaemics have an additive effect (3). Vildagliptin is available in Europe, and sitagliptin, saxagliptin, linagliptin, alogliptin in Europe and the USA (26).

Table V Overview of basic characteristics of CVOT studies with DPP-4 inhibitors.

Tabela V Pregled osnovnih karakteristika CVOT studija sa DPP-4 inhibitorima.

\begin{tabular}{|c|c|c|c|c|c|c|}
\hline $\begin{array}{l}\text { Study name } \\
\text { (reference) }\end{array}$ & Intervention & $\begin{array}{l}\text { Population Characteristics } \\
\text { Type-2 diabetes mellitus and } \\
\text { one of the following: }\end{array}$ & $\mathbf{N}$ & $\begin{array}{l}\text { Mean } \\
\text { Age } \\
(y)\end{array}$ & $\begin{array}{l}\text { Median } \\
\text { Follow-up } \\
\quad(y)\end{array}$ & $\begin{array}{l}\text { Existing } \\
\text { ASCVD } \\
(\%)\end{array}$ \\
\hline $\begin{array}{c}\text { SAVOR-TIMI } 53 \\
(59)\end{array}$ & $\begin{array}{l}\text { Saxagliptin } 2,5 \mathrm{mg} \\
\text { or } 5 \mathrm{mg} \text { once daily } \\
\text { vs. placebo }\end{array}$ & $\begin{array}{l}\text { - Age } \geq 40 \text { y with CAD, CVA, } \\
\text { or PVD. } \\
\text { - Men } \geq 55 \text { y or women } \geq 60 \text { y } \\
\text { with hypertension, } \\
\text { dyslipidemia, or smoking. }\end{array}$ & 16492 & 65 & 2.1 & 78 \\
\hline $\begin{array}{c}\text { CARMELINA } \\
(60)\end{array}$ & $\begin{array}{l}\text { Linagliptin } 5 \mathrm{mg} \\
\text { daily vs. placebo }\end{array}$ & $\begin{array}{l}\text { High CV risk (history of } \\
\text { vascular disease and urine- } \\
\text { albumin creatinine ratio } \\
{[\mathrm{UACR}]>200 \mathrm{mg} / \mathrm{g} \text { ) and/or }} \\
\text { high renal risk ( } \downarrow \text { eGFR and } \\
\text { micro or macroalbuminuria). }\end{array}$ & 6979 & 65.9 & 2.2 & 57 \\
\hline $\begin{array}{l}\text { CAROLINA } \\
\text { (61) }\end{array}$ & $\begin{array}{l}\text { Linagliptin } 5 \mathrm{mg} \\
\text { once daily } \\
\text { Glimepiride } \\
1-4 \mathrm{mg}\end{array}$ & $\begin{array}{l}\text { elevated } \quad \text { cardiovascular } \\
\text { risk(ASCVD, multiple CV risk } \\
\text { factors, } \geq 70 \quad \text { years, } \\
\text { microvascular complications) }\end{array}$ & 6033 & 64.0 & 6.3 & 42 \\
\hline
\end{tabular}

ASCVD, atherosclerotic cardiovascular disease; CAD, coronary artery disease; CVA, cerebrovascular accident; eGFR, estimated glomerular filtration rate; PVD, peripheral vascular disease. 
Five trials enrolling 49,618 patients have been designed to evaluate the CV safety of DPP-4 inhibitors: EXAMINE, SAVOR TIMI 53, TECOS, CARMELINA and CAROLINA (37). No increase or decrease in risk of MACE and mortality due to any cause was observed in any study compared to comparator (37). A slight increase in the incidence of hospitalization due to heart failure in patients on saxagliptin compared to placebo was observed in The SAVOR-TIMI 53 (Saxagliptin Assessment of Vascular Outcomes Recorded in Patients with Diabetes Mellitus-Thrombolysis in Myocardial Infarction trial), although no causal association was found (59). Therefore, caution is advised if saxagliptin is administered to patients with known risk factors for hospitalization due to heart failure (59). Cardiovascular and renal safety in T2DM patients with linagliptin was assessed in two studies with different comparators. Linagliptin versus placebo (the CArdiovascular safety and Renal Microvascular outcomE study with LINAgliptin - CARMELINA study) and linagliptin vs glimepiride (the CARdiovascular Outcome study of LINAgliptin versus glimepiride in patients with type 2 diabetes CAROLINA study) were also neutral with respect to MACE $(60,61)$. Experience in the use of linagliptin in clinical trials in patients with congestive heart failure functional classes III and IV by the New York Heart Association (NYHA) is limited, and caution is required in these patients.

Table VI Overview of cardiovascular end points of CVOT studies with DPP-4 inhibitors.

Tabela VI Pregled kardiovaskularnih ishoda CVOT studija sa DPP-4 inhibitorima.

\begin{tabular}{|c|c|c|c|c|c|c|}
\hline $\begin{array}{l}\text { Study name } \\
\text { (reference) }\end{array}$ & $\begin{array}{l}\text { Composite } \\
\text { 3-point } \\
\text { MACE } \\
\text { (HR) }\end{array}$ & $\begin{array}{c}\text { CV } \\
\text { Death } \\
\text { (HR) }\end{array}$ & $\begin{array}{c}\text { Myocardial } \\
\text { Infarction } \\
\text { (HR) }\end{array}$ & $\begin{array}{c}\text { Stroke } \\
\text { (HR) }\end{array}$ & $\begin{array}{c}\text { Hospitalisation } \\
\text { for unstable } \\
\text { angina } \\
\text { (HR) }\end{array}$ & $\begin{array}{l}\text { Hospitalisation } \\
\text { for heart failure } \\
\text { (HR) }\end{array}$ \\
\hline $\begin{array}{c}\text { SAVOR-TIMI } 53 \\
(59)\end{array}$ & $\begin{array}{c}1.00 \\
(0.89-1.12)\end{array}$ & $\begin{array}{c}1.3 \\
(0.87-1.22)^{1}\end{array}$ & $\begin{array}{c}0.95 \\
(0.8-1.12)^{1}\end{array}$ & $\begin{array}{c}1.11 \\
(0.88-1.39)^{1}\end{array}$ & $\begin{array}{c}1.19 \\
(0.89-1.60)^{1}\end{array}$ & $\begin{array}{c}1.27 \\
(1.07-1.51)^{1}\end{array}$ \\
\hline $\begin{array}{c}\text { CARMELINA } \\
(\mathbf{6 0})\end{array}$ & $\begin{array}{c}1.02 \\
(0.89-1.17)\end{array}$ & $\begin{array}{c}0.96 \\
(0.81-1.14)^{2}\end{array}$ & $\begin{array}{c}1.12 \\
(0.90-1.14)^{2}\end{array}$ & $\begin{array}{c}0.88 \\
(0.63-1.23)^{2}\end{array}$ & $\begin{array}{c}0.87 \\
(0.57-1.31)^{2}\end{array}$ & $\begin{array}{c}0.90 \\
(0.74-1.08)^{2}\end{array}$ \\
\hline $\begin{array}{c}\text { CAROLINA } \\
\text { (61) }\end{array}$ & $\begin{array}{c}0.98 \\
(0.84-1.14)\end{array}$ & $\begin{array}{c}1.00 \\
(0.81-1.24)^{1}\end{array}$ & $\begin{array}{c}1.03 \\
(0.82-1.29)^{1}\end{array}$ & $\begin{array}{c}0.86 \\
(0.66-1.12)^{1}\end{array}$ & $\begin{array}{c}1.07 \\
(0.74-1.54)^{1}\end{array}$ & $\begin{array}{c}1.21 \\
(0.92-1.59)^{1}\end{array}$ \\
\hline
\end{tabular}

HR-hazard ratio (95\% confidence interval), ${ }^{1}$ Secondary outcome, ${ }^{2}$ Exploratory outcome 


\section{Guidelines and reports}

From the EXAMINE study in 2013 until 2018, guidelines that cover pharmacological management of glycaemic control in people with type 2 diabetes did not change significantly $(2,8,62,63)$. In the absence of the need for rescue therapy with insulin, metformin was the first-line drug. The selection and introduction of a new drug(s) were done individually (patient-centred treatment) with no specific recommendation of order and choice. The required efficacy of the agent in achieving glycaemic targets and key patient-related factor were proposed as a general basis for deciding on add-on therapy. The key patient-related factor used for consideration were: significant comorbidities such as atherosclerotic cardiovascular disease, chronic kidney disease (CKD), heart failure (HF), risk of hypoglycaemia, effects on body mass, side effects of the drug administered, drug price, and patient preferences $(2,9)$. Meanwhile, there has been an extensive increase in new evidence indicating $\mathrm{CV}$ benefits from the use of novel glucose-lowering drugs based on large-scale CVOTs. The big paradigm shift with recognition of the cardiovascular and renal benefits of these therapies came with American Diabetes Associations (ADA) Standards of Medical Care in Diabetes for 2018, followed by The Canadian Diabetes Association (Diabetes Canada) clinical practice guideline and ADA and European Association for the Study of Diabetes consensus report (ADA/EASD) in October 2018. $(7,64,65)$. All of these documents continued to promote patient-centred care, with metformin as first-line therapy. The addition of another antihyperglycaemic therapy was recommended only if the HbAlc target was not reached, but the selection of a specific add-on drug was now based on its cardiovascular or renal benefit.

2018 ADA/EASD consensus report endorsed the use of either a sodium-glucose co-transporter 2 inhibitor or a glucagon-like peptide-1 receptor agonist with proven CVD benefit as the metformin add-on therapy in individuals with existing atherosclerotic cardiovascular disease (ASCVD), HF or CKD (7). At that time CVOTs studies were mainly conducted with the subjects who had already manifested cardiovascular disease or multiple CV risk factors, so 2018 ADA/EASD consensus report acknowledged that the findings on the cardiovascular protective effect of the tested drugs could not be extrapolated to non-CVD diabetics (80\%-85\% DM2 patients). Therefore, the choice of additional medication for non-CVD diabetics was conditioned by other important clinical features such as hypoglycaemia, weight change, or drug price (7). For GLP-1 agonists $2018 \mathrm{EASD} / \mathrm{ADA}$ consensus report found the strength of evidence as followed: liraglutide $>$ semaglutide $>$ exenatide with sustained release. With SGLT2 inhibitors, the evidence was slightly stronger for empagliflozin than for canagliflozin. The benefit-risk ratio of using canagliflozin is adversely affected by the reported post-marketing increase of fracture and lower limb amputation $(34,36)$. In this consensus report, SGLT2 inhibitors have an advantage over GLP-1 agonist only in those with heart failure or chronic kidney 
disease, since both empagliflozin and canagliflozin have shown a decrease in the progression of HF and CKD in COVT studies (7). When a patient with manifest ASCVD maintains glycaemic control within an agreed therapeutic target, but with a medication that has no proven CVD benefit, consideration should be given to replacing one of the prescribed medications with one that has proven cardiovascular benefit. Alternatively, priority may be given to the individual glycaemic target values and to introduce antyhiperglicaemic drug with cardiovascular protection property at the time when glycaemic control is impaired (7). A national clinical guideline by Scottish Intercollegiate Guidelines Network (Pharmacological management of glycaemic control in people with type 2 diabetes) was updated in line with the 2018 ADA/EASD consensus report (8).

Since 2019 was the year in which few large CVOTs published their data, a need for an update of the 2018 recommendations on the management of hyperglycaemia, arose. A brief update was published in December 2019 and later became part of ADA guidelines for 2020 (25). The position of metformin as first-line therapy for T2DM was preserved in 2019 update of ADA/EASD consensus report. GLP-1 agonist or SGLT2i also remained the first add-on choice in patients with ASCVD, HF, and CKD. GLP-1 agonists are preferred in patients with established ASCVD and SGLT2is for patients with HF and CKD, based on individual CVOTs results for there are still no head-to-head trials which could provide evidence to recommend a preference for one over the other (25). But the 2019 updated consensus report brought some important changes. First is that GLP-1 agonist or SGLT2 inhibitor should be introduced in appropriate patients for cardiovascular and renal prevention regardless of baseline HbAlc or individualised HbA1c target and second is that they may be used not only in secondary, but also in primary CVD and renal prevention in patients with type 2 diabetes. The ADA/EASD update recognizes that there are little data for patients with $\mathrm{HbAc1}<6,5 \%$, but states that results from CVOTs suggest that the cardiovascular benefits of these drugs are independent of $\mathrm{HbAc1}$ (25). ADA/EASD considers that the level of evidence for MACE benefit from GLP-1 agonists is greatest for the patient with T2DM and established ASCVD presented as prior myocardial infarction, ischaemic stroke, and unstable angina with ECG changes, myocardial ischaemia on imaging or stress test, or revascularisation of coronary, carotid or peripheral arteries. For reduction of the risk of MACE, in patients with type 2 diabetes without established CVD GLP-1 agonists can be considered for: "patients aged 55 years or older with coronary, carotid or lower extremity artery stenosis $>50 \%$, left ventricular hypertrophy, and eGFR $<60 \mathrm{~mL} / \mathrm{min} / 1.73 \mathrm{~m}^{2}$ or albuminuria." ADA/EASD confirms that for the time being the level of evidence to support the use of GLP-1 agonists for primary prevention is presented only for dulaglutide (25). The metaanalysis of the SGLT2 inhibitor CVOTs suggests a class effect to diminish CHF and progression of CKD in both subgroups with high and lower CVD risk with no effect on MACE, beyond glucose-lowering, in patients without established ASCVD (66). Those findings are consistent across all reported trials, although the overall low MACE event 
rate may be due to the short duration of the studies and the small presence of patients with ASCVD. Upon this 2019 ADA/EASD update recommends SGLT2 inhibitors specifically for T2DM patients with or without established atherosclerotic CVD, but with reduced ejection fraction heart failure $(\mathrm{EF}<45 \%$ ) or patients with $\mathrm{CKD}$ (eGFR 30-60 $\mathrm{mL} / \mathrm{min} / 1.73 \mathrm{~m}^{2}$ or the urinary albumin-to-creatinine ratio (UACR) more than $30 \mathrm{mg} / \mathrm{g}$ particularly UACR $>300 \mathrm{mg} / \mathrm{g}$ ). The use of SGLT2is should be carefully assessed in patients with foot ulcers or at high risk for amputation (25).

In September 2019, the European Society of Cardiology (ESC) published Guidelines on diabetes, prediabetes, and cardiovascular disease in collaboration with the EASD (67). This document includes some fundamental differences apart from the 2019 EASD/ADA consensus report. First, metformin is no longer first-line therapy for all patients with T2DM but should be considered mainly in overweight patients with T2DM without CVD and at moderate CV risk (67). ESC guideline recommends that either an SGLT2 inhibitor or a GLP-1 agonist should be prescribed in treatment-naive patients with type 2 diabetes and ASCVD, without having to start metformin first. ESC definitions of individuals without ASCVD who will benefit on utilisation of SGLT2i or GLP-1 agonist are much broader than one given in the 2019 ADA/EASD update. The SGLT2 inhibitors empagliflozin, canagliflozin, or dapagliflozin and the GLP-1 agonists liraglutide, semaglutide, or dulaglutide are recommended to reduce CV events in patients with T2DM and CVD, or at very high/high CV risk (67). Empagliflozin is recommended in patients with T2DM and CVD to reduce the risk of death. Liraglutide is recommended in patients with T2DM and CVD, or at very high/high CV risk, to reduce the risk of death. In patients with established ASCVD, no priority is given to either of the group of novel antihyperglicemics. ESC guideline also assessed glucose-lowering treatment and reduction of HF risk and SGLT2 inhibitors are recommended to lower the risk of HF hospitalization (67). The reason for challenging the position of metformin as first-line drug ESC found in consideration that the benefits of the new therapies did not differ whether patients were on metformin or not (metformin was background therapy in over $70 \%$ of the participants in the cardiovascular outcomes trials). Thus, choice of the further therapy in patients with clinical CVD may not primarily depend on background therapy. Starting two antihyperglycaemic therapies simultaneously, or starting metformin first then add a GLP-1 agonist or SGLT2 inhibitor later would augment polypharmacy and could delay the provision of medicines proven to reduce cardiovascular events (67).

But not everyone was eager to change the recommendations based on the CVOTs. In March 2018 National Institute for Health and Care Excellence (NICE) published Evidence reviews on the clinical effectiveness of SGLT-2 inhibitors and GLP-1 agonists on cardiovascular outcomes to provide recommendations for the update of the NICE guideline on type 2 diabetes management in adults (NG28) (68). This work did not update any of the NICE technology appraisals and the position on the use of novel 
antihyperglicemic drugs stayed as previous. Although the committee noted that they are aware of other trials that are yet to be published and which should be taken into consideration in a future update of this guideline, no new recommendations are available yet (62).

\section{Conclusion}

The dramatic increase in the prevalence of type 2 diabetes mellitus in the last 30 years and the association of this disease with other high-prevalence non-communicable diseases such as obesity, atherosclerotic cardiovascular disease, chronic kidney disease, and metabolic syndrome have forced the health and scientific community into pursuit on finding new solutions for control and prevention of this type of diabetes. In the past ten years, special attention has been paid to the investigation of the cardiovascular effects of antihyperglycemic drugs. While the trials data looks favourable and promising, they do not bring needed clarity in deciding on routine clinical practice with regards to prescribing particular medications. Thorough consideration of deprescribing is needed in a situation when a new agent is added to a regimen containing the traditional antihyperglycaemic agents, particularly in patients at or near glycaemic goals. The treatment with a GLP-1 agonist or SGLT2 inhibitor in some healthcare settings implies significant costs for patients. In the absence of uniform recommendations, attention to patient-specific factors and preferences should drive individualised clinical decisions.

Further research into the pleiotropic effects of new groups of drugs and the pathophysiological mechanisms of the disease itself will probably bring new paradigms for the treatment of glucose and insulin homeostasis disorders.

\section{References}

1. American Diabetes Association. Classification and Diagnosis of Diabetes Mellitus: Standards of Medical Care in Diabetes-2019. Diabetes Care 42 (January):13-28.doi:10.2337/dc19-S002.

2. Milašinović G. Nacionalni vodič dobre kliničke prakse za dijagnostikovanje i lečenje diabetus melllitusa, Republička stručna komisija za izradu i implementaciju vodiča dobre kliničke prakse 2013.

3. Powers AC, Dalesio D. Endocrine Pancreas and Pharmacotherapy of Diabetes Mellitus and Hypoglycemia u Goodman and Gilmans The Pharmacological Basis of Therapeutics 13th ed. USA McGraw-Hill Education, 2018.

4. American Diabetes Association. 10. Cardiovascular Disease and Risk Management: Standards of Medical Care in Diabetes-2020 Diabetes Care 43 (Supplement 1) (January): 111-134, 2020 doi.org/10.2337/dc20-S010. 
5. Acharya T, Deedwania P. Cardiovascular outcome trials of the newer anti-diabetic medications. Prog Cardiovasc Dis [Internet]. 2019;62(4):342-8. Available from:

https://doi.org/10.1016/j.pcad.2019.08.003.

6. Rang HP, Dale MM.The control of blood glucose and drug treatment of diabetes mellitus u Rang and Dale's Pharmacology 7th Ed., Elsevier Inc.2012.

7. Davies MJ, D'Alessio DA, Fradkin J et al (2018) Management of hyperglycaemia in type 2 diabetes, 2018. A consensus report by the American Diabetes Association (ADA) and the European Association for the Study of Diabetes (EASD). Diabetologia. 61(12):2461-2498. https://doi.org/10.1007/s00125-018-4729-5.

8. Scottish Intercollegiate Guidelines Network (SIGN). Pharmacological management of glycaemic control in people with type 2 diabetes. Edinburgh: SIGN; 2017. (SIGN publication no. 154). [November 2017]. dostupno na : http://www.sign.ac.uk.

9. American Diabetes Association 6. Glycemic Targets: Standards of Medical Care in Diabetes-2020 Diabetes Care 43 (Supplement 1): S66-S76. 2020 doi.org/10.2337/dc20-S006.

10. Action to Control Cardiovascular Risk in Diabetes Study Group, Gerstein HC, Miller ME, et al. Effects of intensive glucose lowering in type 2 diabetes. N Engl J Med. 2008;358(24):2545-2559. doi:10.1056/NEJMoa0802743.

11. ADVANCE Collaborative Group, Patel A, MacMahon S, et al. Intensive Blood Glucose Control and Vascular Outcomes in Patients with Type 2 Diabetes. N Engl J Med [Internet]. 2008 Jun 12;358(24):2560-72. Available from: https://doi.org/10.1056/NEJMoa0802987.

12. Agrawal L, Azad N, Bahn GD, et al. Long-term follow-up of intensive glycaemic control on renal outcomes in the Veterans Affairs Diabetes Trial (VADT). Diabetologia. 2018;61(2):295-299. doi:10.1007/s00125-017-4473-2.

13. King P, Peacock I, Donnelly R. The UK prospective diabetes study (UKPDS): clinical and therapeutic implications for type 2 diabetes. $\mathrm{Br}$ J Clin Pharmacol. 1999;48(5):643-648. doi:10.1046/j.1365-2125.1999.00092.x.

14. Agrawal L, Azad N, Bahn GD, et al. Long-term follow-up of intensive glycaemic control on renal outcomes in the Veterans Affairs Diabetes Trial (VADT). Diabetologia. 2018;61(2):295-299. doi:10.1007/s00125-017-4473-2.

15. Brownrigg JR, Hughes CO, Burleigh D, Karthikesalingam A, Patterson BO, Holt PJ, et al. Microvascular disease and risk of cardiovascular events among individuals with type 2 diabetes: a population-level cohort study. Lancet Diabetes Endocrinol.2016;4(7):588-97. https://doi.org/10.1016/S2213-8587(16)30057-2.

16. Juutilainen A, Lehto S, Ro"nnemaa T, Pyorala“ K, Laakso M. Retinopathy predicts cardiovascular mortality in type 2 diabetic men and women. Diabetes Care 2007;30(2):292-9. https://doi.org/10.2337/dc06-1747.

17. Taqueti VR, Di Carli MF. Coronary Microvascular Disease Pathogenic Mechanisms and Therapeutic Options: JACC State-of-the-Art Review. J Am Coll Cardiol. 2018;72(21):2625-41. https://doi.org/10.1016/ j.jacc.2018.09.042. 
18. Lee AK, Warren B, Lee CJ, Mcevoy JW, Matsushita K, Huang ES. The Association of Severe Hypoglycemia With Incident Cardiovascular Events and Mortality in Adults With Type 2 Diabetes. 2018;41(January):104-11.

19. Pozzilli P, Leslie RD, Chan J, De Fronzo R, Monnier L, Raz I, et al. The A1C and ABCD of glycaemia management in type 2 diabetes: a physician's personalized approach. DiabetesMetab Res Rev. 2010;26(4):239-44. https://doi.org/10.1002/dmrr.1092.

20. Nissen SE, Wolski K. Effect of rosiglitazone on the risk of myocardial infarction and death from cardiovascular causes. N Engl J Med 2007 Jun 14;356(24):2457-71. https://doi.org/10.1056/NEJMoa072761.

21. Center for Drug Evaluation and Research (CDER). Guidance for Industry Diabetes Mellitus Evaluating Cardiovascular Risk in New Antidiabetic Therapies to Treat Type 2 Diabetes. U.S. Department of Health and Human Services Food and Drug Administration. December 2008.

22. European Medicines Agency. Guideline on clinical investigation of medicinal products in the treatment or prevention of diabetes mellitus 29 January 2018 CPMP/EWP/1080/00 Rev. 2.

23. Gerstein HC, Holman RR, Zinman B, et al. Cardiovascular Outcomes Trials in Type 2 Diabetes : Where Do We Go From Here? Ref lections From a Diabetes Care Editors' Expert Forum. 2018;41(January):14-31. doi:10.2337/dci17-0057.

24. Schnell O, Standl E, Catrinoiu D, et al. Report from the 4th Cardiovascular Outcome Trial (CVOT) Summit of the Diabetes \& Cardiovascular Disease (D \& CVD) EASD Study Group. Cardiovasc Diabetol. 2019:1-8. doi:10.1186/s12933-019-0822-4.

25. Buse JB, Wexler DJ, Tsapas A, Rossing P, Mingrone G, Mathieu C, et al. 2019 update to: Management of hyperglycaemia in type 2 diabetes, 2018. A consensus report by the American Diabetes Association (ADA) and the European Association for the Study of Diabetes (EASD). 2020;221-8.

26. Antidiabetics u Martindale. The Complete Drug Reference. 39th ed. London. The Pharmaceutical Press, 2017.

27. Study C. Sodium-glucose Co-transporter-2 Inhibitors in Type 1 Diabetes - a Dangerous Ally. 2017;1:75-78.

28. Agencija za lekove i medicinska sredstva Republike Srbije. Sažetak karakteristika leka: Byetta® 5 mikrograma/doza, rastvor za injekciju u napunjenom injekcionom penu. 2018. Dostupno na: https://www.alims.gov.rs/ciril/files/lekovi/smpc/515-01-02439-17-001.pdf Datum pristupa 25.09.2019. godine.

29. DeFronzo RA, Norton L, Abdul-Ghani MN. Renal, metabolic and cardiovascular considerations of SGLT2 inhibition. Nat Rev Nephrol 2017;13(1):11-26. https://doi.org/10.1038/nrneph.2016.170.

30. Heerspink HJ, Perkins BA, Fitchett DH, Husain M, Cherney DZ. Sodium Glucose Cotransporter 2 Inhibitors in the Treatment of Diabetes Mellitus: Cardiovascular and Kidney Effects, Potential Mechanisms, and Clinical Applications. Circulation 2016;134(10):752-72. https://doi.org/10.1161/CIRCULATIONAHA.116.021887.

31. FDA Announcement. Drug safety communication: FDA warns that SGLT2 inhibitors for diabetes may result in a serious condition of too much acid in the blood 5-15-2015 
32. European Medicines Agency. PRAC SGLT2 inhibitors: recommendations to minimise risk of diabetic ketoacidosis 12/02/2016.

33. FDA Announcement. Drug safety communication: FDA warns about rare occurrences of a serious infection of the genital area with SGLT2 inhibitors for diabetes.

34. FDA Announcement. Drug safety communication: FDA revises label of diabetes drug canagliflozin (Invokana, Invokamet) to include updates on bone fracture risk and new information on decreased bone mineral density. 2015.

35. Ueda P, Svanström H, Melbye M, et al. Sodium glucose cotransporter 2 inhibitors and risk of serious adverse events: nationwide register based cohort study. 2018;(December 2016):1-10. doi:10.1136/bmj.k4365.

36. FDA Announcement. Drug safety communication: FDA confirms increased risk of leg and foot amputations with the diabetes medicine canagliflozin (Invokana, Invokamet, Invokamet XR). $2017 ; 2$.

37. Gerstein HC, Holman RR, Zinman B, Skyler JS, Green JB, Buse JB, et al. Cardiovascular Outcomes Trials in Type 2 Diabetes: Where Do We Go From Here? Ref lections From a Diabetes Care Editors' Expert Forum. 2018;41(January):14-31.

38. Zinman B, Wanner C, Lachin JM, Fitchett D, Bluhmki E, HantelS, et al. EMPA-REG OUTCOME Investigators. Empagliflozin, Cardiovascular Outcomes, and Mortality in Type 2 Diabetes. N Engl J Med 2015; 373(22): 2117-28. doi: 10.1056/NEJMoa1504720.

39. Agencija za lekove i medicinska sredstva Republike Srbije. Sažetak karakteristika leka: Jardiance ${ }^{\circledR}$ film tablete 30x10mg. 2015. Dostupno na: https://www.alims.gov.rs/ciril/files/lekovi/smpc/515-0101671-14-001.pdf.

40. Neal B, Perkovic V, Mahaffey KW, de Zeeuw D, Fulcher G, Erondu N, et al. CANVAS Program Collaborative Group.Canagliflozin and Cardiovascular and Renal Events in Type 2 Diabetes. N Engl J Med 2017; 377(7): 644-657. doi: 10.1056/NEJMoa1611925.

41. Schnell O, Standl E, Catrinoiu D, et al. Report from the 3rd Cardiovascular Outcome Trial (CVOT) Summit of the Diabetes \& Cardiovascular Disease (D \& CVD) EASD Study Group. Cardiovasc Diabetol. 2018:1-6. doi:10.1186/s12933-018-0667-2.

42. Wiviott SD, Raz I, Bonaca MP, Mosenzon O, Kato ET, Cahn A, et al. DECLARE-TIMI 58 Investigators. Dapagliflozin and Cardiovascular Outcomes in Type 2 Diabetes. N Engl J Med 2019; 380(4): 347-357. doi: 10.1056/NEJMoa1812389.

43. McMurray JJV, Solomon SD, Inzucchi SE, Køber L, Kosiborod MN, Martinez FA, et al. DAPA-HF Trial Committees and Investigators. Dapagliflozin in Patients with Heart Failure and Reduced Ejection Fraction. N Engl J Med 2019; 381(21): 1995 -2008. doi: 10.1056/NEJMoa1911303.

44. Perkovic V, Jardine MJ, Neal B et al (2019) Canagliflozin and renal outcomes in type 2 diabetes and nephropathy. N Engl J Med 380(24):2295-2306. https://doi.org/10.1056/NEJMoa1811744.

45. FDA Official Label for JARDIANCE (empagliflosin)

https://www.accessdata.fda.gov/drugsatfda_docs/label/2020/204629s023lbl.pdf

Revised: $1 / 2020$. 
46. FDA Official Label for INVOCANA (canagliflosin)

forhttps://www.accessdata.fda.gov/drugsatfda_docs/label/2020/204042s036lbl.pdf Revised:

$01 / 2020$

47. FDA Official Label for FARXIGA (dapagliflosin)

https://www.accessdata.fda.gov/drugsatfda_docs/label/2020/202293s020lbl.pdf Revised: 05/2020.

48. Powers AC, NiswenderKD, Rickels MR. Diabetes Mellitus: Management and Therapies in Harrisons Principles of Internal Medicine 20th ed.USA McGraw-Hill Education, 2018.

49. Sposito AC, Berwanger O, Carvalho LSF De, Francisco J, Saraiva K. GLP - 1RAs in type 2 diabetes: mechanisms that underlie cardiovascular effects and overview of cardiovascular outcome data. Cardiovasc Diabetol. 2018:1-19. doi:10.1186/s12933-018-0800-2.

50. Al Tulaihi B, Alhabib S. Uncertainties around incretin-based therapies: A literature review. Saudi Pharm J. 2017;25(1):1-7. doi:10.1016/j.jsps.2015.06.009.

51. European Medicines Agency. Eperzan Withdrawal of the marketing authorisation in the European Union. 2018;44(November):824408.

52. Novo Nordisk. Novo Nordisk files oral semaglutide for US regulatory approval of glycaemic control, as well as for CV risk reduction for oral semaglutide and Ozempic ${ }^{\circledR}$. Company announcement No 18 / Apr. 2019.

53. Marso SP, Daniels GH, Brown-Frandsen K, Kristensen P, Mann JF, Nauck MA, et al. LEADER Steering Committee; LEADERTrial Investigators. Liraglutide and Cardiovascular Outcomes in Type 2 Diabetes. N Engl J Med 2016; 375(4): 311-22. doi:10.1056/NEJMoa1603827.

54. Marso SP, Bain SC, Consoli A, Eliaschewitz FG, Jo'dar E, Leiter LA, et al. SUSTAIN-6 Investigators. Semaglutide and cardiovascular outcomes in patients with type 2 diabetes. N Engl J Med 2016; 375(19): 1834-1844.

55. Gerstein HC, Colhoun HM, Dagenais GR, Diaz R, Lakshmanan M, Pais P, et al. REWIND Investigators. Dulaglutide and cardiovascular outcomes in type 2 diabetes (REWIND): a doubleblind, randomised placebo-controlled trial. Lancet 2019; 394(10193): 121-130. doi: 10.1016/S01406736(19)31149-3.

56. Husain M, Birkenfeld AL, Donsmark M, Dungan K, Eliaschewitz FG, Franco DR, et al. PIONEER 6 Investigators. Oral Semaglutide and Cardiovascular Outcomes in Patients with Type 2 Diabetes. N Engl J Med 2019; 381(9): 841-851. doi:10.1056/NEJMoa1901118.

57. Holman RR, Bethel MA, Mentz RJ, Thompson VP, Lokhnygina Y, Buse JB, et al. EXSCEL Study Group. Effects of Once-Weekly Exenatide on Cardiovascular Outcomes in Type 2 Diabetes. N Engl J Med 2017; 377(13): 1228-1239. doi: 10.1056/NEJMoa1612917.

58. Pfeffer MA, Claggett B, Diaz R, Dickstein K, Gerstein HC, Køber LV, et al. ELIXA Investigators. Lixisenatide in Patients with Type 2 Diabetes and Acute Coronary Syndrome. N Engl J Med 2015; 373(23): 2247-57. doi: 10.1056/NEJMoa1509225.

59. Scirica BM, Bhatt DL, Braunwald E, Steg PG, Davidson J, Hirshberg B, et al. SAVOR-TIMI 53 Steering Committee and Investigators. Saxagliptin and cardiovascular outcomes in patients with type 2 diabetes mellitus. N Engl J Med 2013;369(14):1317-26. https://doi.org/10.1056/NEJMoa1307684. 
60. Rosenstock J, Perkovic V, Johansen OE, Cooper ME, Kahn SE, Marx N, et al. CARMELINA Investigators. Effect of Linagliptin vs Placebo on Major Cardiovascular Events in Adults With Type 2 Diabetes and High Cardiovascular and Renal Risk: The CARMELINA Randomized Clinical Trial. JAMA 2019; 321(1): 69-79. doi: 10.1001/jama.2018.18269.

61. Rosenstock J, Kahn SE, Johansen OE, Zinman B, Espeland MA, Woerle HJ, et al., CAROLINA Investigators. Effect of Linagliptin vs Glimepiride on Major Adverse Cardiovascular Outcomes in Patients With Type 2 Diabetes: The CAROLINA Randomized Clinical Trial. JAMA 2019 Sep 19. doi: 10.1001/jama.2019.13772.

62. NICE guideline Type 2 diabetes in adults: management (NG28) Published: 2 December 2015 www.nice.org.uk/guidance/ng28 Last updated August 2019.

63. American Diabetes Association. 8. Pharmacologic Approaches to Glycemic Treatment: Standards of Medical Care in Diabetes-2017. Diabetes Care 40 (Supplement 1): S64-S74 https://doi.org/10.2337/dc17-S011.

64. American Diabetes Association. Pharmacologic Approaches to Glycemic Treatment: Standards of Medical Care in Diabetes-2019. Diabetes Care 42(January):90-102. doi:10.2337/dc19-S009

65. Lipsombe L, Booth G, Butalia S, Dasgupta K, et al. Diabetes Canada 2018 Clinical Practice Guidelines for the Prevention and Management of Diabetes in Canada: Pharmacologic Glycemic Management of Type 2 Diabetes in Adults. Can J Diabetes 2018;42(Suppl 1):S88-S103.

66. Zelniker TA, Wiviott SD, Raz I et al (2019) Comparison of the effects of glucagon-like peptide receptor agonists and sodium glucose cotransporter 2 inhibitors for prevention of major adverse cardiovascular and renal outcomes in type 2 diabetes mellitus.Circulation. 139(17):2022-2031. https://doi.org/10.1161/CIRCULATIONAHA.118.038868.

67. Grant PJ, Cosentino F. The 2019 ESC Guidelines on diabetes, pre-diabetes, and cardiovascular diseases developed in collaboration with the EASD: New features and the 'Ten Commandments' of the 2019 Guidelines are discussed by Professor Peter J. Grant and Professor Francesco Cosentino, the Task Force chairmen. Eur Heart J. 2019 Oct 14;40(39):3215-3217. doi: 10.1093/eurheartj/ehz687.

68. NICE Guideline Updates Team, Type 2 diabetes in adults: management (NG28) Evidence reviews for SGLT-2 inhibitors and GLP-1 mimetics March 2018. 


\title{
Uloga novih antihiperglikemika u terapiji šećerne bolesti tipa 2 - od kontrole glikemije do kardiovaskularne zaštite
}

\author{
Tatjana Žunić*, Milojka Ponjavić
}

Apoteka Beograd, Velimira Bate Živojinovića 16/4, 11000 Beograd, Srbija

*Corresponding author: Tatjana Žunić, E-mail: tzunic@sbb.rs

\begin{abstract}
Kratak sadržaj
Pojava novih antihiperglikemika ne samo da je donela veći izbor lekova koji se koriste za kontrolu glikemije, već je uvela promene i u drugim važnim aspektima terapije dijabetesa tipa 2 (T2DM) kao što su kardioprotekcija i renoprotekcija. Svi novi antihiperglikemici: inhibitori natrijum-glukoza kotransportera 2 (SGLT2i), agonisti receptora za glukagonu-sličan peptid-1 (GLP-1 agonisti) i inhibitori dipeptidil peptidaze-4 (DPP-4i) bili su predmet ispitivanja multicentričnih prospektivnih placebo kontrolisanih studija $u$ kojima su ispitivani kardiovaskularni ishodi (engl. Cardiovascular Outcome Trials - CVOT). Ipak, zapaženi kardioprotektivni efekti se ne smatraju svojstvom klase, posebno u grupi GLP-1 agonista, već su osobenost pojedinačnih predstavnika grupe. Na osnovu rezultata CVOT-a neki lekovi su dobili registrovanu indikaciju od Uprave za hranu i lekove (engl. Food and Drug Administration, FDA) za smanjenje rizika od velikih neželjenih kardiovaskularnih događaja kod odraslih sa šećernom bolešću tipa 2 i utvrđenim kardiovaskularnim bolestima (liraglutid, semiglutid, dulaglutid, kanagliflozin, empagliflozin, dapagliflozin). Kardiološka i dijabetološka društva priznala su rezultate CVOT-a na različite načine. Američka asocijacija za dijabetes (engl. American Diabetes Associations - ADA) i Evropska asocijacija za studije u dijabetesu (engl. European Association for the Study of Diabetes - EASD) još uvek smatraju metformin lekom prvog izbora, ali su uveli precizne kriterijume za korišćenje GLP-1 agoniste i SGLT2i kako u sekundarnoj, tako i u primarnoj prevenciji kardiovaskularnih (KV) bolesti. Kanadsko udruženje za dijabetes (Diabetes Canada) prepoznalo je upotrebu antihiperglikemika sa pokazanom KV koristi samo u sekundarnoj prevenciji. Evropsko društvo za kardiologiju (eng. European Society of Cardiology - ESC) dalo je prednost kardioprotektivnim efektima i odabralo GLP-1 agoniste i SGLT2i za terapiju prve linije kod novodijagnostikovanih T2DM pacijenta sa aterosklerotskom kardiovaskularnom bolešću (ASKVD). Nacionalni institut za izvrsnost u zdravstvu i nezi u Velikoj Britaniji (engl. National Institute for Health and Care Excellence - NICE) nije promenio predhodnu poziciju o primeni novih antihiperglikemijskih lekova samo za postizanje zadovoljavajuće kontrole glikemije bilo kao monoterapije kad je primena metformina kontraindikovana ili postoji intolerancija bilo kao dodatne terapije $\mathrm{u}$ dvojnim i trojnim kombinacijama antihiperglikemijskih lekova.
\end{abstract}

Ključne reči: šećerna bolest tipa 2, kardioprotekcija, inhibitori natrijum-glukoza kotransportera 2 (SGLT2i), agonisti receptora za glukagonu-sličan peptid-1 (GLP-1 agonisti), ispitivanja kardiovaskularnih ishoda 